How to reference this article Czabanowska-Wróbel, A. (2015). Asymetria dwóch „małych literatur”. Italica Wratislaviensia, 6, 321-325. DOI: http://dx.doi.org/10.15804/IW.2015.06.20

Anna Czabanowska-Wróbel

Uniwersytet Jagielloński

anna.czabanowska-wrobel@uj.edu.pl

\title{
ASYMETRIA DWÓCH „MAŁYCH LITERATUR”
}

Monika Woźniak, Katarzyna Biernacka-Licznar, Bogumiła Staniów (2014). Przekłady w systemie matych literatur. O włosko-polskich i polsko-włoskich tlumaczeniach dla dzieci i młodzieży. Toruń: Wydawnictwo Adam Marszałek, ss. 290.

$\mathrm{D}$ awno temu, bo jeszcze w latach trzydziestych XX w., Paul Hazard postawił tezę o większym znaczeniu literatury dziecięcej i, szerzej, kultury dziecięcej w krajach Europy Północnej i w literaturze anglosaskiej niż w Europie Południowej i w literaturach romańskich ${ }^{1}$. Ten wybitny socjolog kultury swoje stanowisko uzasadniał między innymi poślednim miejscem dziecka w świecie romańskim i większym znaczeniem dzieciństwa w Anglii, której znakiem rozpoznawczym były szkoły z internatem. Dziś, w czasach globalizacji, w odmiennych warunkach społecznych i mimo wielorakich zmian społecznego znaczenia dzieciństwa, wciąż jeszcze obserwacja ta jest trafna. Światowa popularność Harry'ego Pottera z wykreowanym w powieściach J.K. Rowling obra-

1 Hazard, P. (1963). Ksią̇ki, dzieci i dorośli (tłum. I. Słońska). Warszawa: Wydawnictwo „Nasza Księgarnia”. 
zem mitycznej szkoły magii jest czytelnym dowodem ciągłości pewnej tradycji literackiej. W Europie niesłabnący wpływ natury pedagogicznej wywierają też „małe” literatury skandynawskie, zwłaszcza w języku szwedzkim. Na tym tle włoskie książki dla dzieci - prócz genialnego Pinokia, obrastającego z czasem w nowe znaczenia - nie wywarły większego wpływu na zbiorową wyobraźnię na całym świecie.

Pozycja polskiej literatury dziecięcej jest z kolei dużo niższa niż włoskiej. W światowej recepcji nie reprezentuje Polski ani jedno rozpoznawalne dzieło, brak bowiem utworu, który byłby jednocześnie specyficzny dla naszego kraju, uniwersalny, a na dodatek wybitny. W swoich rozważaniach francuski uczony nie brał, rzecz jasna, pod uwagę literatury polskiej, ale z łatwością wpisałby ją w schemat takiej kultury, w której dzieciństwo było traktowane jako czas pełnego ponagleń oczekiwania na dorosłość, nie zaś autonomiczny etap życia. Trzeba się z tym pogodzić: żadna polska książka dla dzieci (mimo wielu świetnych dokonań współczesnych polskich wydawców i ilustratorów) nie miała tej rangi, co jedno włoskie arcydzieło o drewnianym dziecku samotnego ojca-stwórcy.

Przy porównaniu z literaturą włoską polska literatura dziecięca zawsze będzie skazana na swego rodzaju komparatystyczną „,niewspółmierność", na wyraźną asymetrię związaną z innym typem recepcji i ,peryferyjnym" charakterem.

Współautorki monografii dotyczącej zarówno przekładów włoskiej literatury dziecięcej w Polsce, jak i, znacznie uboższego, zasobu tłumaczeń polskich książek dla dzieci we Włoszech podjęły się zadania polegającego na wnikliwym zbadaniu i opisaniu dwóch literackich światów i ich asymetrycznej relacji. Komparatystyczne ujęcie trzech badaczek, które opracowały również niezbędną do dalszych badań fundamentalną bibliografię przekładów polskich i włoskich książek dziecięcych, to niezwykle potrzebna i cenna pozycja, rzecz, jakiej dotychczas nie było.

W pierwszej części monografii Monika Woźniak kreśli zarys zagadnień teoretycznych związanych z komparatystyką translatologiczną w dziedzinie literatury dziecięcej. Następnie rysuje mapę obecności i nieobecności dzieł włoskich i polskich. Wielka trudność komparatystyki związana jest z tym, że chodzi tu nie tylko o porównanie samych 
przekładów i ich kontekstów, ale o toczący się stale dialog wzajemnych wyobrażeń, na który - jakby tego było mało - nakłada się nie mniej ważny, wewnętrzny dialog danej wspólnoty narodowej na temat jej samej. Niewidzialna, zarazem realna „wspólnota wyobrażona” przemawia do dzieci na rozmaite sposoby. Jak przypomina Tomasz Bilczewski: „Taka wspólnota ma charakter odczuwalny, wiąże się z pewną powtarzalnością praktyk społecznych, dbałością o podtrzymanie określonego zespołu przekonań, mitów, wartości, które powstają w swoistym akcie wyobraźni”’”.

Oczekiwanie, że thumacze literatury dziecięcej w każdym przypadku i bez uproszczeń zmierzą się z całym bogactwem wspólnot narodowych, nie może się spełnić. Dawni thumacze stosowali znaną strategię czynienia bliskim tego, co obce, i w Polsce postępowano tak często do połowy XX w., nadając na przykład polskie imiona dziecięcym postaciom z książek obcych. Tłumacze czy adaptatorzy włoscy stosowali z kolei wobec literatury polskiej zasługującą na wnikliwą uwagę strategię akcentowania słowiańskiej inności, jednak ze znamiennym (a dla nas niesatysfakcjonującym) sprowadzaniem tego, co specyficznie polskie, do wspólnego słowiańskiego mianownika. Czytelnik monografii z żalem dostrzeże więc powierzchowną stylizację słowiańską czy - niestety - wschodniosłowiańską, jak to opisuje Monika Woźniak, w przypadku powieści O krasnoludkach i sierotce Marysi. Stacho i Jaśko u Konopnickiej zamieniają się w wersji włoskiej w „Stiepę” i „Ivana” (s. 84), co jeszcze uzupełnia ilustracja ukazująca Królową Tatrę w kokoszniku na głowie.

$\mathrm{Na}$ marginesie tego wątku podpowiadam źródło jednej z reprodukowanych ilustracji: „,bizantyjski” w stylu król Krak z ilustracji do zbioru legend i podań polskich (s. 116) to wizerunek cesarza Ottona III z miniatury z ewangeliarza. Paradoksem jest to, że włoscy wydawcy polskich baśni sięgnęli po ten wizerunek: obraz w całości przedstawiał także składające hołd Ottonowi kobiece personifikacje Rzymu, Germanii, Galii i Słowiańszczyzny.

2 Bilczewski, T. (2014). „Imagi - natio”. Przekład a wspólnota wyobrażona. Poznańskie Studia Polonistyczne, Seria Literacka 23 (43), 69. 
Druga część monografii, autorstwa Katarzyny Biernackiej-Licznar, przedstawia syntetyczny zarys dziejów włoskiej literatury dziecięcej w Polsce do 1945 r. Cezura ta jest jak najbardziej uzasadniona historycznie i literacko, chociaż dla przekładów z literatur zachodnich w Polsce nie mniej ważna jest data przełomu październikowego 1956 (z poprawką na cykl wydawniczy: 1957), kiedy to po „odwilży” ruszyła fala tłumaczeń blokowanych dotychczas ideologicznie.

Chcę wskazać jeden tylko, subiektywnie przez mnie wybrany, przykład niezwykle ciekawego odkrycia przez autorkę zapomnianej książki dla dzieci i całkiem też zapomnianej pisarki, Bianki Marii Viviani, której melancholijne, lapidarne Legendy o kwiatach z roku 1922 z nastrojowymi, utrzymanymi w klimacie Art Nouveau ilustracjami Marii De Matteis ukazały się w polskim przekładzie Zuzanny Rabskiej w roku 1926. Historia książki i odkrycia badaczki zainteresowała mnie z powodów osobistych. Otóż mam jej egzemplarz, który należał do mojej mamy, wydobyty spod gruzów Warszawy po powstaniu, pozbawiony pierwszych stron, a więc także nazwiska autorki. Takich naukowych znalezisk popartych gruntownymi badaniami składająca się z trzech części książka przynosi więcej.

Trzecia część monografii, autorstwa Bogumiły Staniów, nosi znamienny tytuł A jednak Pinokio! i dotyczy literatury włoskiej w Polsce w latach 1945-2012. Mogłoby to być motto całej książki, ponieważ dzieło Collodiego zwycięża ostatecznie wszystkie inne książki dziecięce, stając się wizytówką Włoch w Polsce i na świecie. Opowieść o przekładach włoskich książek dla dzieci w Polsce pozwala uchwycić znamienną prawidłowość. Od połowy XX w. można odnotować, jak stwierdza Bogumiła Staniów, ,stały spadek liczby edycji dzieł De Amicisa oraz zwiększone zainteresowanie Collodim i nierówne Rodarim" (s. 266). Nota bene ciekawy jest fenomen dwóch mających różne przyczyny fal tłumaczeń Rodariego, tej najnowszej i tej z lat pięćdziesiątych, skądinąd tak ubogich w przekłady zachodniej literatury. „Słuszne” poglądy pisarza były wtedy jego przepustką do zamkniętej za „żelazną kurtyną” Polski.

Monografia przybliża pośrednio wiele cech charakterystycznych dla obu „wspólnot wyobrażonych”. Jeden z przykładów podobieństwa 
to duża i długotrwała rezerwa wobec angielskich książek dziecięcych, uznawanych i w Polsce, i we Włoszech za niedziecięce, trudne w odbiorze, nazbyt abstrakcyjne czy absurdalne, czego dowodem było długotrwałe niechętne nastawienie do Alicji w Krainie Czarów i jej wyraźnie opóźniona recepcja w obu krajach.

Wśród współczesnych polskich pośredników między dwiema kulturami nie sposób pominąć Jarosława Mikołajewskiego, który sam jest autorem wierszy dla dzieci: tłumacza, wraz z Magdaleną Mikołajewską, niełatwego, wielopiętrowego, zawierającego fragmenty wierszowane, utworu Dina Buzzatiego Slynny najazd niedźwiedzi na Sycylię.

Polski odbiorca zainteresowany baśnią (nie jest to wyłącznie odbiorca dziecięcy) ma od niedawna pełny dostęp do trzech tomów monumentalnych a literacko doskonałych Baśni włoskich Itala Calvina. Nowe wydanie, zawierające również komentarze autora, zastępuje jednotomowy, bardziej „dziecięcy”, pięknie zresztą zilustrowany przez Wiesława Majchrzaka wybór z roku 1968. Wybitne dzieła włoskie w doskonałych polskich przekładach bardzo cieszą, ale nie przyczynią się do zmniejszenia zasygnalizowanej przeze mnie w tytule asymetrii.

Owa niełatwa do przezwyciężenia asymetria, którą można lepiej zrozumieć po lekturze Przekładów w systemie malych literatur..., wynika przede wszystkim z nieprzerwanego (nawet $\mathrm{w}$ trudnych politycznie czasach) otwarcia kultury polskiej na to, co docierało do niej z Italii, i swoistego zamknięcia, obojętności kultury włoskiej na to, co polskie, oceniane jako zarazem niedostatecznie bliskie i nie dość egzotyczne. Jakie byłyby sposoby na to, by choć trochę przezwyciężyć trudności wzajemnego poznawania się za pośrednictwem literatury dziecięcej? Prawdziwej szansy na zmiany upatrywałabym w sile polskiej szkoły ilustracji, która w XXI w. znowu, jak kiedyś w latach siedemdziesiątych $\mathrm{XX}$ w., przeżywa swój rozkwit. Być może to właśnie nasze najlepsze książki ilustrowane przemówią za pośrednictwem tłumaczy do kolejnych pokoleń włoskich dzieci? 